\title{
40 Years of IMWA in Poland
}

\author{
Andrzej J. Witkowski ${ }^{1}$ (D)
}

Received: 10 April 2021 / Accepted: 9 June 2021 / Published online: 19 June 2021

(c) Springer-Verlag GmbH Germany, part of Springer Nature 2021

Poland, as a country with a strongly developed mining industry and substantial problems related to water in mines, has made relevant contributions to the development of mine water research. Many years of activity by Polish hydrogeologists (especially Zbigniew Wilk, Andrzej Różkowski, Marek Rogoż, Andrzej Szczepański, and Jacek Motyka) have produced a number of interesting, high-quality archival studies, design projects, reports, case studies, expert evaluations, scientific papers, and books in the area of Upper Silesia.

For over 40 years, Polish hydrogeologists have been successfully developing methods for reliably assessing and forecasting the environmental impact of mine closure and reclamation. This led to the development of effective cooperation between Polish hydrogeologists and the burgeoning International Mine Water Association (IMWA) in 1979, i.e., the year that IMWA was formally established. One of the founders of IMWA was the Polish hydrogeologist Jacek Libicki, who served on the IMWA Executive Council from 1979 to 1982 . In recognition of his contributions to the development of IMWA, he became one of its first Honorary Members. This aforementioned cooperation was reflected both in the organization of scientific conferences under the auspices of IMWA as well as joint publications (e.g., Wolkersdorfer et al. 2012) and the participation of Polish hydrogeologists in international projects implemented by IMWA (ERMITE, CoSTaR).

One of the first large international symposia organized by IMWA was on the "Hydrogeology of Coal Basins", which was hosted and organized by the University of Silesia in Katowice, Poland in 1987, and co-organized with the International Association of Hydrogeologists (IAH) and the Polish Academy of Sciences. 140 people from 20 countries participated. Interesting presentations were given concerning hydrogeological exploration, characteristics of coal basins,

Andrzej J. Witkowski

andrzej.witkowski@us.edu.pl

1 Institute of Earth Sciences, University of Silesia in Katowice, 41-200 Sosnowiec ul. Będzińska 60, Katowice, Poland and forecasting of mining-induced hydrogeological changes. The symposium programme also included two interesting one-day field trips (to Bełchatów, the largest lignite open pit mine in Europe and one of the largest in the world, and a trip around the Upper Silesia Coal Basin).

This symposium was attended by a number of important figures in the history of IMWA, including: Rafael F. Rubio of Spain (then president and one of the founders of IMWA), the first three Honorary Members of IMWA (Zsolt Kesseru of Hungary, and Jacek Libicki and Marek Rogoż of Poland), three later IMWA presidents (Ernest Kipko of the former Soviet Union), Donald Armstrong of Australia and Andrzej Witkowski of Poland), and four individuals who were members of the IMWA Executive Council at the time or subsequently (Vladimir Straskraba of the USA, Peter Norton and Raghu N. Singh of the UK, and Jacek Motyka of Poland). This symposium resulted in the publication of a 606-page conference proceedings containing 54 articles divided in four topics (Wilk 1987). All papers can be downloaded for free at IMWA's web page: http://www.IMWA. info/proceedings 1987.

The most important IMWA events are its Congresses, which are organised every 3 years. The 7th IMWA Congress was held in 2000 in Ustron, Poland, a picturesque health resort in the Beskidy Mountains. 128 people from 23 countries participated in this congress. The Ustron Congress was attended by 26 important representatives of the IMWA Executive Council. In addition to the 11 forementioned participants of the Katowice symposium, these included: Christian Wolkersdorfer of Germany - long term General Secretary of IMWA (2000-2017) and current President, four former IMWA Presidents: Miran Veselič of Slovenia, Peet Nel of South Africa, Adrian Brown of the USA, and John Waterhouse of Australia, four former IMWA Vice Presidents: Adam Jarvis and Richard Connelly of the UK, Thomas Rüde of Germany, and Bob Kleinmann of the USA (also an Honorary Member and long term Editor-in-Chief of this journal), two other Honorary IMWA Members: Colin Dudgeon of Australia, and Paul Younger of the UK, and also three Councillors: Nad’a Rapantová of the Czech Republik, 
Antonio Bertachini of Brasil, and Onofrio Sammarco of Italy.

The rich program of the Congress included: four plenary sessions (Fig. 1), a poster session, two optional mid-congress field trips to Upper Silesia (desalination plant, ground subsidence, anthropogenic floodplains, mine waste dumps) and to $\mathrm{Zn}-\mathrm{Pb}$ ore mines in the Olkusz region, meetings of the IMWA Executive Council and General Assembly, and a three day post-congress excursion to the Bełchatów mine, the picturesque natural landscape of the CracowCzęstochowa Jurassic upland, the beautiful and historic old city in Cracow (a UNESCO world heritage site), and the spectacular medieval Wieliczka salt mine (also a UNESCO world heritage site).

The 671-page proceedings volume of the 7th IMWA Congress contains 62 papers on environmental effects of mining, mine closure and reclamation, utilisation of mine water and mine wastes, and numerical modelling (Różkowski and Rogoż 2000). Again, these papers can be freely downloaded from: http://www.IMWA.info/proceedings2000.

It should be mentioned that at this Congress, a new IMWA board was elected: Peet Nel became President, Christian Wolkersdorfer became General Secretary, Adrian Brown became Treasurer, and three Vice Presidents were elected: Peter Norton, Vladimir Straskraba, and Andrzej Witkowski.

In summary, we can say that 9 (out of 10) of IMWA's Presidents and 7 (out of 8) IMWA's Honorary Members attended one or both IMWA meetings that Poland hosted. Unfortunately, Zsolt Kesseru, Ernest Kipko, Jacek Libicki, Vladimir Straskraba, and Paul Younger are no longer with us. We honour their memory! We also honour the memory of the late Professor Andrzej Różkowski, an excellent hydrogeologist who initiated the establishment of the Hydrogeology Department at the University of Silesia and mentored many Polish hydrogeologists, including myself.

I personally take pride in having initiated and organized international field workshops for young hydrogeologists at the University of Silesia. These workshops have been conducted since 2010. Workshops programs vary, comprising keynote lectures by experienced hydrogeologists from universities, oral and poster presentations prepared by young hydrogeologists, field training, courses on groundwater monitoring and modelling, in addition to interesting geological and hydrogeological field trips. One of the important topics of these workshops is mining hydrogeology. The workshops gave participants an excellent opportunity to become familiar with research conducted by various national and international scientific bodies and was an effective forum for exchanging experiences and views on recent important issues, including groundwater contamination, monitoring and protection, groundwater in karstic areas, geothermal water, and intensive groundwater drainage by mines and well fields). Two of these workshops (in 2014 and 2015) were coorganized by the Polish Association of Hydrogeologists and the Polish National Chapters of IAH and IMWA.

The 2014 workshop was hosted by the Faculty of Earth Sciences of the University of Silesia in Sosnowiec, an industrial city situated within the Upper Silesian Coal Basin. This workshop attracted 38 participants from nine countries (Poland, Slovakia, Ukraine, Denmark, Finland, Turkey, Serbia, Iran, and South Africa). The theme of the workshop was "Intensive groundwater drainage" (Dąbrowska and Witkowski 2014). In addition to the traditional technical sessions (22 oral and poster presentations), short courses were provided on ArcHydro Groundwater and AQUAVEO. There was also an optional field trip to active $\mathrm{Zn}-\mathrm{Pb}$ or coal mines, and the pleasure of punting along the Black Trout Adit in the old abandoned $\mathrm{Pb}-\mathrm{Zn}-\mathrm{Ag}$ ore mine in Tarnowskie Góry (another UNESCO world heritage site).

The 2015 workshop, in Sosnowiec and Bełchatów, focused on the "Human Impact on Groundwater" (Czekaj et al. 2015), was attended by 30 students from Poland, Ukraine, Belgium, Australia, Germany, Ireland, and Morocco. Students gave five presentations and presented eight posters. 13 participants attended a groundwater flow modelling course "Introduction to FEFLOW". Field sessions
Fig. 1 One of the Congress 2000 sessions; in the image, besides others, are R.F. Rubio, M. Veselič, J. Libicki, A. Brown, R. Kleinmann, A. Bertachini, J. Waterhouse, Peet Nel, Rob Bowell, Richard Connely, T. Rüde, and A. Różkowski (image courtesy K. Rubin)

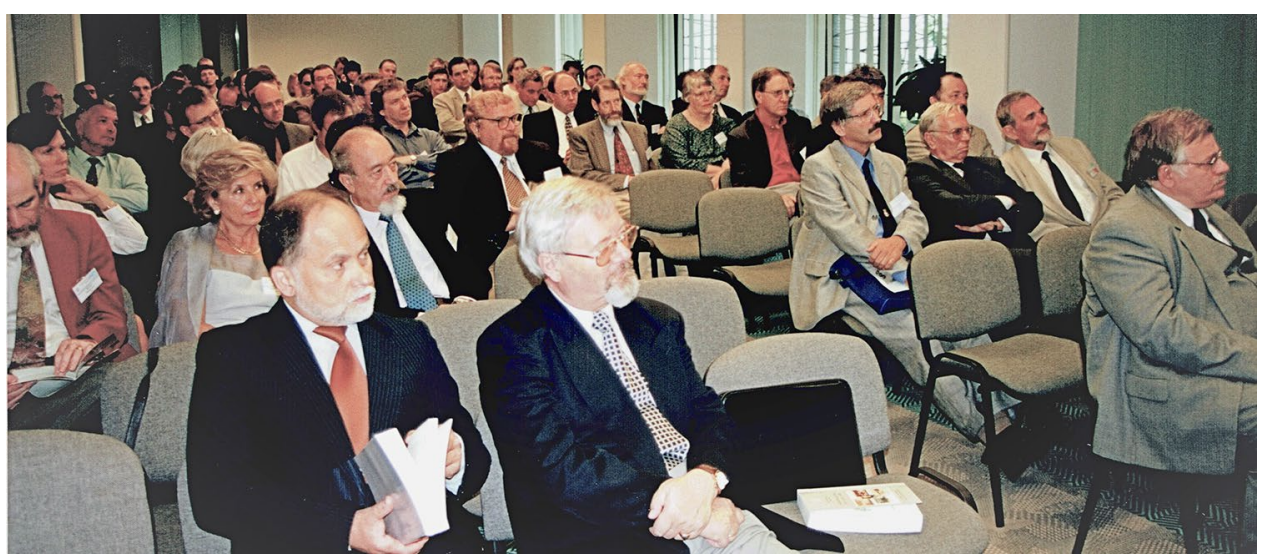


were held at the Bełchatów lignite mine with its automated dewatering system of hundreds of wells and participants had the opportunity to see groundwater from the mine dewatering being bottled for sale by the BEWA company.

It is also worth noting the harmonious cooperation of Polish hydrogeologists with both the IAH and IMWA. In addition to co-organization of symposia and workshops, there were joint publications. A good example was the XXXVII IAH Congress organized in Cracow in 2010. Mine water problems ("Groundwater quality and mining") were an important topic, with 20 oral presentations and 11 posters presented. A special issue of the Polish journal "Przegląd Geologiczny" ("Polish Geological Review") was produced, in which an extensive article entitled "What Polish mining owes to Polish hydrogeology?" was published (Kowalczyk et al. 2010). In the same issue, "The complex hydrogeology of the unique Wieliczka salt mine" (Brudnik et al. 2010) was also published. Recently, an article on "Mining Enterprises \& Groundwater" was published on the IAH website as part of its strategic overview series (Foster et al. 2018).

In conclusion, it should be stated that Polish hydrogeologists take pride in their involvement with IMWA, which included the election of Andrzej Witkowski as Vice President, and later President of IMWA. Also, two outstanding Polish hydrogeologists (Jacek Libicki and Marek Rogoż) became Honorary IMWA Members and Jacek Motyka was elected an IMWA Councillor.

\section{References}

Brudnik K, Czop M, Motyka J, d'Obyrn K, Rogoż M, Witczak (2010) The complex hydrogeology of the unique Wieliczka salt mine. Przeglad Geol 58(9/1):787-796
Czekaj J, Jakóbczyk-Karpierz S, Sitek S (eds) (2015) Abstracts, VI International field workshop for young hydrogeologists, Bełchatów. University of Silesia, Sosnowiec

Dąbrowska D, Witkowski AJ (eds) (2014) Abstracts, V International field workshop for young hydrogeologists on intensive groundwater drainage. Faculty of Earth Sciences University of Silesia, Sosnowiec

Foster S, Tyson G, Timms W, Witkowski A, Foot S, Peiyue L, Johnstone A (2018) Mining enterprises \& groundwater. International Assoc of Hydrogeologists Strategic Overview Series https://iah. org/wp-content/uploads/2018/12/IAH_SOS_MiningEnterpris esGroundwater.pdf

Kowalczyk A, Witkowski A, Różkowski A, Szczepański A, Rogoż M, Przybyłek J, Staśko S (2010) What Polish mining owes to Polish hydrogeology. Przegląd Geol 58(9/1):775-786

Różkowski A, Rogoż M (eds) (2000) Mine water and the environment. Proc, 7th International Mine Water Association Congress, Uniwersytet Śląski. Główny Instytut Górnictwa, Katowice

Wilk Z (ed) (1987) Hydrogeology of Coal Basins. Proc, International Symp, Katowice, Wyd. AGH, Kraków

Wolkersdorfer C, Bowell B, Walder IF, Nilssen S, Räisänen ML, Heikkinen P, Pulkkinen K, Korkka-Niemi K, Veli-Pekka S, Destouni G, Hasche A, Witkowski AJ, Blachère A, Morel S, Lefort D, Midžić S, Silajdzic I, Coulton RH, Wiliams KP, Rees B, Hallberg KB, Johnson DB (2012) Erratum to: contemporary reviews of mine water studies in Europe, part 2. Mine Water Environ 31(3):237-238

Publisher's Note Springer Nature remains neutral with regard to jurisdictional claims in published maps and institutional affiliations. 